\title{
Financial Crisis and the Cyclical Changes of Financial Supervision
}

\author{
Baodong Ren \\ Business School Wenzhou University \\ Business School, Wenzhou University, Wenzhou Higher Education Park, Wenzhou, 325035, P.R.China \\ Tel: +86-577-8870-2315, +86-137-5871-0157Ｅ-mail: wsyrbd@163.com
}

Received: April 20, 2011 Accepted: May 5, 2011 doi:10.5430/ijfr.v2n2p27

Sponsoring information: The research is financed by the Science \& Technological foundation of Wenzhou China (R20100040, R20090122)

\begin{abstract}
:
This article is to search the underlying reasons of financial crisis and economic cycle. This article, from a new Angle of view(human nature), explain the reasons of economic crisis and its cycle, reveals the interaction of capital greed and financial supervision in the process of economic cycle and the inevitability of economic crisis in capitalism's system. Conclusion: because the progress of science and technology and the development of social economy cannot continue to meet the need of capital greed, capital will collectively seek institutional breakthrough-relaxing on financial supervision Relaxed financial supervision make capital win more profit space, but also lead to the rampancy of capital greed, and then cause economic bubble and economic crisis. Economic crisis makes people to seek the new, strict financial supervision. Economic cycles arise there from.
\end{abstract}

Key words: Financial crisis, Financial supervision, Subprime mortgage crisis, Economic cycle, Greed human nature

\section{Introduction}

Capital has the greedy nature, which is determined by the greed of human nature. Since capital was produced, the greed of capital has been tending to give a negative impact and disaster on the society and economy, in addition to its positive effect. Certainly, from then on, financial supervision have been accompanying by capital, which make the greed of capital not go so far as to destroy completely the entire society and economy. The greed of capital is consistent and unchanging, the same as invariability of human nature, and while financial supervision are strong at times and weak at other times and periodically changing, the disaster caused by the greed of capital also periodically come into the world. The periodical change of financial supervision is also caused by the greed of capital. This America financial crisis has proved the above-mentioned viewpoints. This crisis is caused by the weakening of financial supervision on previous period which has brought rampant greed of capital. In the post-crisis era, financial supervision will periodically tend to be strengthened.

\section{The Freed of Capital and the Greed of Human Nature}

Humanity itself has it's both sides, True and false, beauty and ugliness, goodness and evil and so on. Greed and contentment are also two sides of human nature. General speaking, on both sides of human nature, each side approximately accounted for $50 \%$, but on both sides of the greed and contentment, human nature in modern capitalist society focused on greed. Whether individual, collective, or ethnic group, nation, they strive for front rank in benign or malignant competition. And greed is the driving force of striving. Contentment is only the temporary performance of the other side of human nature for a few individuals at some stage, which is individual case and special case.

Greed means a desire that men want to grab money, material wealth or physical gratification far more than Own needs. Man's desires are unlimited, and this is reason what we refer to man's desire as greed.

The greed of capital is from the greed of human nature. Greedy nature of individual, collective, and the state, which have possessed of or mastered the capital, gives capital the rapacious nature. The greed of capital is as follows:

\subsection{To pursue the maximization of investment return under the existing rules}

The classical economic theory suppose the existing rules (the capitalist system) is perfect, the greedy nature of capital (self-interested, rational) will maximize wealth, at the same time in the "exchange" that is a human nature, create a ideal society (this is the positive role of capital greed). However, the assumption of the classical economic theory is wrong. Rules and systems of human society are impossibly perfect, they are historical, and will eventually change with the 
development of history. Therefore, the negative effects of capital greed are ever-present. For example, "the uneven distribution of wealth" and "cyclical fluctuations of economy" exist in different historical periods. The rules of different periods have different financial supervision, and the negative effects which are brought by capital greed are different.

\subsection{To break rules, and to pursue of greater return on investment by hook or by crook}

When the profit space of capital has not available space under the existing rules, most capitals with the greedy nature will break rules to pursue illegally and unscrupulously greater profits. Such examples are numerous.

2.3To seek modification of rules, and to pursue legally a greater investment return under the new rules.

When the profit space of capital has not available space under the existing rules and environment, capitals with the greedy nature have the collective impulse to modify the existing rules. The new rules will provide the capital greed with a larger profit space.

\section{The Cyclical Changes on Financial Supervision}

Business cycle theory has been widely accepted. For the reason of the economic cycle, there are "external cause theory", such as war, revolution, election, development of new land and technologies, scientific breakthroughs and technological innovations, etc; and "internal cause theory", such as multiplier- accelerate number principle, speculative mentality theory, etc. In fact, from another perspective, the economic cycle are also accompanied by cyclical changes in financial supervision. Economic cycles and financial supervision cycle are reciprocal causation and affect each other. Relaxation of financial supervision will bring indulgent behavior of capital greed. Indulgent behaviors of capital bring economic expansion and then generate a huge economic bubble. When capital greed ultimately makes economic bubble break, the economy will become into depression, and then especially in the case of great depression the collective rationality in turn will request strengthen financial supervision. There are not big economic bubbles and great depressions generally in strong financial supervision time, but capital profitability is also strongly astricted. When profit space of capital is badly short and economy continues to falter, the collective rationality would request to relax financial supervision, then there will be the next economic bubble and recession. The cyclical changes in financial supervision are a endogenous factors in cyclical development process of the economy. Therefore, that cyclical changes on financial supervision brought about cyclical changes of economy should be "internal cause theory."

The trace of changes on financial supervision can be found in the economic cycle and the Great Depression in American history. The late 19th century and early 20th century, monopoly capital have great development, financial capital become the dominant force of capitalism. Development of financial market, innovations of financial products and financial system, and the lack of third-party financial supervision make financial supervision greatly relax. Wreak havoc of capital greed finally caused the Great Depression of the world economy in 1929-1933. Subsequently, the U.S. President Roosevelt carry out "New Deal" and strengthen the Government's intervention in economy, a variety of new policies and institutions make financial supervision strengthened. Until 70s after World War II, the United States has no major bubble economy and depression in the Keynesian policy. In the 1970s, for various reasons (of course, the Keynesianism is one of reasons), the U.S. economy turn up stagflation, profit margins of capital is badly lacking. As a result, there turn up a wave of neo-liberalism. Financial supervision loosen and supervision of financial derivatives are cancelled. These had promoted economic growth by using the greed of financial capital in order to meet the greed of the whole society until the occurrence of this financial and economic crisis.

\section{This Weak Financial Supervision Time and the Rampant Process of Capital Greed}

\subsection{This relaxation of financial supervision}

A weak financial supervision has been put on the stage also before this financial crisis outbreak. Greed of capital is increasingly rampant among the weak financial supervision time, and then the huge bubble is produced, eventually leading to the financial crisis and economic crisis.

As said in 3., the U.S. economy turn up stagflation and profit margins of capital is badly lacking in the 1970s, and then there turn up neo-liberalism, financial supervision loosen in 80s.

4.1.1 The provision of divided operation has been broken in financial institutions, and banks can take greater risks in venture investment.

The U.S. Congress introduced "the bill of thrift institutions deregulation" (Gramm-Leach-Bliley) under continued and strong lobbying of Wall Street in 1999, then the Glass-Steagall act is officially abolished. The provisions of divided operation have been broken in financial institutions, financial services chain are formed by financial institutions, financial capital can more easily engage in financial innovation, and avoid financial supervision, acquire excess profits. 


\subsubsection{Financial asset securitization, the supervision on financial risk is weaken}

In the 1980s, the most significant change of the U.S. financial sector was the expansion of the securitization process. Assets that can be not resold changed into securities that can be resold. Housing mortgage loans, and the subsequent self-help loans and credit card receivables almost without exception existed in the form of portfolio of commercial banks and savings banks, and were traded as securities in the secondary market. Issuance, service holding, and credit allocation was disintegrated as a distinctive range of services of Banks and savings and loan institutions. At the same time, the interest rate risk of banks in floating interest rate environment and the risk of toxic assets also have been disintegrated, and ultimately the risk subsided down the system.

Government guarantors played an important role in the process of securitization and changes of the mortgage market. Federal National Mortgage Association (FNMA), Government National Mortgage Association (GNMA) and Federal Home Loan Mortgage Corporation (FHLMC) purchase collateral issued by sponsored institutions, or provide insurance for these collateral, then issue (or permit issuance) collateralized mortgage obligations, and these bonds are guaranteed by the Federal Highway Administration or the Veterans Administration.

\subsubsection{Floating interest rates make junk-bond market have a large development and speculative capital has a new venue}

Floating interest rates expand profit margins of financial capital and spark speculation of financial capital. Changes in interest rates and rate of inflation make enterprises seek fixed-rate financing and investors seek higher-yielding investment opportunities, which promoted development of the junk bond market.

4.1.4 Various types of financial derivatives emerge in endlessly, which makes the greed of speculative capital come into play.

Chicago Board of Trade (CBOT) and Chicago Mercantile Exchange (CME) began to appear forward financial products in 1972, including contract of sale debit tools of the U.S. treasury bonds and pledged securities. In 1982, the introduction of stock index futures would result in "portfolio insurance scheme." In 1973, standardized options began to trade after establishing The Chicago Futures Trading Commission. Afterwards "credit default insurance" would impute risk to insurance companies, then insurance companies impute again risk to other by insurance contracts securitization, the risk would subside in the system. Before the financial crisis began the dimensions of financial derivatives are inflated from 780 billion U.S. dollars to 62 trillion dollars.

4.1.5 Broker dead commission regulation is relieved, which reducing the cost of speculative trading.

In 1975, deregulation of brokerage commission regulation reduces transaction costs and increase transaction efficiency and also increases speculation of the capital, because the cost of speculative trading has also been reduced.

\subsubsection{Life insurance risk transfer, insurance companies reduce the risk constraint}

Guarantee system of life insurance protects the policyholders and passes the risk of bankruptcy of the insurance company on to taxpayers at the same time. The risk constraint of insurance companies is reduced, so that the impulse of the insurance capital greed is increased.

4.1.7 The degree of freedom of competition is increased, mergers and monopolies of the capital is prevailed

Obstruction of regional competition and impede competition in the industry is weakened, horizontal mergers are in vogue, the company appear macro-scale and diversification. Restrictions of financial institutions to establish branches and horizontal merger have been lifted.

4.1.8 The operation of financial markets can pass through computer automation, which make financial innovation and a large number of movements and speculative of capital possible.

Computers cover various financial markets and promote financial integration, reduce barriers to capital movements. At the same time, the computer can handle more and more complex transactions and cope with constantly distensible volume of transactions, which make new financial instruments pricing theory was invented by financial expert practical application.

4.1.9 The loose monetary policy of the FED provides basis for the greed of capital.

\subsection{The rampant process of capital greed on this occasion}

In 1986, chief executive officer (CEO) of a large company, Ivan Boesky, said a very famous word in a graduation ceremony of business school of University of California, “Greed is alright!” which became a classic and well-known saying of business world. Greed has been rationalized. In the financial crisis triggered by the current U.S. subprime mortgage crisis, innovation and chasing benefits in financial derivatives gives full expression to capital greed. In the 
chasing benefits process, "credit default swap" (CDS) product of the financial industry is an important platform for chasing benefits.

The rampant process of capital on this occasion take the house mortgage purchase subprime loans as a starting point, "credit default insurance" (CDS) as a platform, , bankruptcies of "Merrill Lynch" and "Lehman Brothers" as a sign of collapse.

\subsection{1 "Credit default swap" (CDS) product}

Loans purchase house financial system before subprime loans first require borrowers to pay the down payment of $20 \%$ of total to denote borrowers' responsibility, second require the total number of loans can not exceed 4 times of borrower's annual income, that is to say, banks at most lend 40 million to households whose annual income is 10 million on the purchase houses. This is the most basic financial product, this product make that many young couples who can not formerly afford a house can have an own house, and realize their "American dream." More importantly, this product led to economic growth.

This basic financial product is good. Because responsibilities and risks of banks and borrowers are very clear and very easy to calculate. Borrowers know that they are likely to lose their property and the first payment of $20 \%$ of total if they could not pay monthly loan; banks know that they will be closed and their business qualification will be abolished by the Government if bad loans have reached a certain level. Financial activities keep smooth running under the balance of responsibility and risk.

Due to "credit default swap" (CDS) products, banks can sell the risk of bank loans to insurance companies, banks pay a certain insurance expenses and insurance company compensate the default loss. Hence, it is stable and no risk for banks to make money, and the risk is borne entirely by insurance companies. As a result, bank lending is crazy in order to maximize the benefits. In order to release more loans, the down payment of $20 \%$ of total is canceled, and even the income of borrowers is not reviewed, and become that everyone can buy a house, real estate market certainly become very active, house prices continually go up. House prices rise more quickly to stimulate the real estate market. Because a family may buy many houses as investments in the case of no down payment.

Insurance companies calculated the risk of loans, and the premium of high-risk loans was also increased. After purchasing a large number of housing loans of a great many banks, insurance companies created a new product by packaging and sell it to another financial institution to obtain an immediate profit. The financial institution repackaged the product and then sold it to another financial institution. Each new packaging is more complex than the last, so that the most primitive loans risk constantly change hands.

Loose monetary policy of the FED provides ample liquidity for credit scale expansion and the expansion of CDS. In this way the snowball is getting bigger, the aggregate market value of CDS contracts at the highest time can be up to 62 trillion U.S. dollars.

\subsubsection{The optimistic economy expectations}

From the buyers' point of view, there is no risk of down payment, but they would pay for monthly installment payment, and the interest of sub-prime is about twice the general one. But the U.S. financial system can allow buyers to use other loans and credit card overdraft to pay sub-prime loans since the wave of liberalism. Buyers put it this way because of the optimistic expectations on the economy. House prices will always go up. The house can be sold to repay everything even to the inability to repay the loan. At least they stay in the house on the cuff for some time. The formation of foam is from the people's confidence in the first place. Everyone is optimistic about the economic outlook, so that people tend to consume more or investment consumption. When people have more consumer demand, they often tend to look for financial system. The financial systems think that economic prospects are good, and lending not only can get interest, but also the risk is very low. Their views are no different from ordinary people. As a result, the confidence generates credit expansion. As soon as the credit expands, demand is driven up. The demand pull drives further economic growth. When economy gets growth, people's confidence is greater. As a result, the confidence and the credit generate self-loop, and this self-loop mechanism will develop into a bubble, which will be ruined when it reached a certain degree.

\subsubsection{The burst of the bubble}

Price is not always to go up, and the economy is not likely to keep high growth all the time under the impetus of the bubble, because the bubble economy has not the support of the real economy, the real economy is unable to keep pace with growth of the bubble economy (virtual economic). When expectations of inflation became stronger and stronger, the FED began raising interest rates, more and more people could not pay the loan every month in the U.S., then housing sales and prices began to fall, people began to lose confidence, and the bubble began to burst. 
When more and more people in the United States could not pay the loan monthly, insurance company would go out of business. As soon as insurance company closed down, it would not cash insurance for the bank, bank also should close down. Incidentally, foreign investment companies who bought CDS securities also have to swallow all the losses. Those loans securities are simply worthless. When the virtual mansion constructed by the CDS is about to dump, finally, Merrill Lynch flatly sold, 36 billion U.S. dollars of bonds only sold 6 million. But even so Merrill Lynch also can not avoid the final bankruptcy. The next case is the fact that we are facing today, that the financial crisis from the United States sweep the global.

Sub-prime loans itself is not large in fact, the direct bad debts caused by the U.S. sub-prime, is only 780 billion U.S. dollars in the real estate, but investment banks make a leverage, Lehman Brothers made 100 million U.S. dollars to 6 billion U.S. dollars, or more. In the U.S., leverage ratio of most of the investment banks is 30:1, Lehman Brothers reached 60:1, Fannie Mae and Freddie Mac reached 100:1. In the time of earning money, using financial leverage can make big money, conversely, make a big lose in the time of losing money. For example, Fannie Mae and Freddie Mac make a deal with 100:1 leverage ratios, amount of the capital is 100 billion U.S. dollars, while the price of their selling product has $1 \%$ fluctuation toward the opposite direction of its judgments, it means that the 10 billion U.S. dollars will be all lost in a moment, and odds is $100 \%$.

Lever became longer and longer, the fulcrum became more and more weak. Sub-prime loans had been tremendous amount of vast, while life of the real estate was hanging by a thread. As long as the poor have no money to repay, it should be likely to be the first piece of dominoes to pull down the fragile sub-prime pyramid. However, no one played anxiety-ridden at the crowd carnival feast. All Inflection point that might turn things around were slurred over. Everyone was drunk, governments were drunk. No one is clear in mind. The train which loaded with countless dreams of wealth went to the abyss with no suspense.

This is results of capital greed, but also is results of whole society greed.

\section{In Post-crisis Era, the Financial Supervision Will Be Periodically Tended to Strengthen}

\subsection{United States President Barack Obama has come up with policy ideas of the divided operation in financial industry.}

In order to limit excessive risk-taking behavior and avoid the recurrence of crises, in June 21, 2009, U.S. President Barack Obama proposed proposal of financial reforms to set permanent barrier to the scale and nature of business of the big banks on Wall Street. Among them, greatly risky proprietary trading is key restriction object, involving Goldman Sachs, Morgan Stanley and JP Morgan Chase and other large institutions. The new proposal is also a part of reform of large-scale financial regulation from White House, whose emphasis will focus on proprietary trading of financial institutions. A proprietary trading is the transaction that a bank carries out for its own funds, whose investment area involves securities, commodities, derivatives, hedge funds, private equity firms and other financial products.

\subsection{The United States Congress came up with a bill of comprehensive financial reform.}

In March 15, 2010, the U.S. Senate Banking Committee chairman, democratic senator Christopher Dodd published a new reform bill of financial regulation. According to the latest bill, the right of the U.S. Federal Reserve (FED) will expand.

5.2.1 The scope of regulation of the FED extends to the big banks whose assets are more than 50 billion U.S. dollars;

5.2.2 A new consumer finance rights and interests protection agency is founded attached to the Federal Reserve. The agency can monitor the bank whose assets are more than 10 billion U.S. dollars and supervise mortgage lending related to consumer interests, as well as insurance companies and other non-bank financial institutions;

5.2.3 The financial stability oversight board directly leaded by Ministry of Finance and composed of nine members will be set up. The committee will be responsible for supervising systemic risk of financial institutions and directly lead the Federal Reserve to supervise largest crossing-state financial institutions in the United States. The object of supervision is not just banks;

5.2.4 Federal Deposit Insurance Corporation have regulatory powers to the bank whose scale is less than 50 billion U.S. dollars, shareholders have the right to take non-binding vote for remuneration of the management layer;

5.2.5 The 50 billion fund funded by a large financial institution is established to pay for the failure costs of large financial institutions and avoid taxpayers foot the bill;

5.2.6 Hedge funds whose scale is more than 100 million U.S. dollars have to register in the Securities and Exchange Commission. 


\section{Conclusion}

Financial supervision can be enhanced. However, the capitalism system can not solve the contradiction between greed of capital and economic development.

The separate operation not only reduces the risk of bank, but also makes the profits of bank drop significantly. Under separate operation, profits of commercial bank are from the real economy (lending to the real economy, make profits by interest margin between deposit and loan interest rate). However, the profits provided by the real economy are thin day by day, labor costs and operating costs of the bank continue to rise (that is also the result of greed). In the absence of major science and technology revolution and the large-scale transition of industry case, the profits of the real economy and the risk constitute has been difficult to support bank that rely on loan for survival. And the investment bank that there is no commercial banks to support will be easier to go bankrupt in volatile capital markets.

Scientific and technological progress and socio-economic development can not satisfy the greed of capital, in the circumstances of narrow profit margins day by day, the capital will collectively seek a breakthrough in the system and relax financial supervision. Relaxation of the restraint makes greed of capital unbridled and thereby causes economic bubble and the economic crisis. The result of depression makes people look for strict constraints on capital.

The existing capitalism system hasn't yet found mechanism to solve the contradiction between greed and real economic development. Therefore, the cyclical changes of financial supervision and cyclical arrival of the economic crisis will keep up.

Countermeasures research of Wenzhou modern industrial cluster cultivation and industrial transformation and upgrading

\section{References}

Bingzhi, Hu, \& Bing, Wang. (1999). Effect Mechanism of Market Punishment on Risk Control of Financial System. Economy review. No.6. pp.85-89.

Conglai, Fan. (1994). Modern financial institution. Nanjing: Nanjing University Press..

Fujing, Ye. (2001). Comparative Study for Universal Banking. Beijing: China Financial Publishing House.

Hengsen, Fan. (2000). Explore to Science of Financial System. Beijing: China Financial Publishing House

Jian, Gao. (2009a). The United States Announced Outline of Reform Scheme for Financial Regulation. available: http://www.cs.com.cn/yh/02/200906/t20090617_2118121.html.

Jian, Gao. (2009b). The United States Announced Reform Plans for Financial Regulation System. available: http://www.cs.com.cn/XwZX/15/090618/04/200906/t20090618_2119146.htm

Peng,Xie. (2009). Reflex of the United States Announced Reform Scheme for Financial Regulation. available: http://www.cs.com.cn/xwzX/15/090618/04/200906/t20090618_2119921.htm.

Wenbing, Duan. (2010). Institutional Economics. Shanghai: Shanghai Language Education Press. 